\title{
Preparing Sc-Bearing Master Alloy Using Aluminum-Magnesium Thermoreduction Method
}

\author{
Junhui Xiao ${ }^{1,2,3, * \mathbb{C}}$, Wei Ding ${ }^{1}$, Yang Peng ${ }^{1}$, Tao Chen ${ }^{1}$ and Kai Zou ${ }^{1}$ \\ 1 Sichuan Provincial Engineering Lab of NonMetallic Mineral Powder Modification and High-Value \\ Utilization, Southwest University of Science and Technology, Mianyang 621010, China; \\ dingwei@mails.swust.edu.cn (W.D.); pengyang@mails.swust.edu.cn (Y.P.); \\ chentao@mails.swust.edu.cn (T.C.); zoukaiswust@163.com (K.Z.) \\ 2 Key Laboratory of Sichuan Province for Comprehensive Utilization of Vanadium and Titanium Resources, \\ Panzhihua University, Panzhihua 617000, China \\ 3 Key Laboratory of Ministry of Education for Solid Waste Treatment and Resource Recycle, \\ Southwest University of Science and Technology, Mianyang 621010, China \\ * Correspondence: xiaojunhui33@163.com; Tel.: +86-139-9019-0544
}

Received: 20 June 2020; Accepted: 13 July 2020; Published: 16 July 2020

\begin{abstract}
In this study, preparation of $\mathrm{Al}-\mathrm{Mg}-\mathrm{Sc}$ master alloy tests were carried out by $\mathrm{Al}-\mathrm{Mg}$ thermoreduction method. Stirring by blowing argon and pressing with molten salt jar were adopted to reduce scandium segregation and upgrading scandium recovery of scandium-bearing master alloy. The results show that the Al-Mg-Sc master alloy ingot contained $2.90 \% \mathrm{Sc}, 5.73 \% \mathrm{Mg}, 0.0058 \% \mathrm{Cu}$, $0.29 \%, 0.029 \% \mathrm{Ti}, 0.13 \% \mathrm{Fe}, 0.075 \% \mathrm{Zn}, 0.025 \% \mathrm{Na}$, and $96.72 \%$ recovered scandium obtained under the comprehensive conditions used: $m(\mathrm{Al}): m(\mathrm{Mg}): m\left(\mathrm{ScCl}_{3}\right)=10: 1: 1.5$, stirring speed of eight rpm, reduction temperature of $1223 \mathrm{~K}$, reduction time of $40 \mathrm{~min}$. The experimental results are in agreement with the thermodynamic predictions, and $\mathrm{Al}-\mathrm{Mg}-\mathrm{Sc}$ master alloy indicator was ideal.
\end{abstract}

Keywords: scandium; Sc-bearing master alloy; aluminum-magnesium thermoreduction; scandium chloride

\section{Introduction}

Al-Sc alloy has the advantages of low specific gravity, high strength, good plasticity, good high temperature resistance, good corrosion resistance, good welding performance, etc. The Bayikov Metallurgical Research Institute of Russian Academy of Sciences and all of Russia Light alloy research institutes successively has developed $\mathrm{Al}-\mathrm{Mg}-\mathrm{Sc}, \mathrm{Al}-\mathrm{Zn}-\mathrm{Mg}-\mathrm{Sc}, \mathrm{Al}-\mathrm{Mg}-\mathrm{Li}-\mathrm{Sc}, \mathrm{Al}-\mathrm{Zn}-\mathrm{Mg}-\mathrm{Cu}-\mathrm{Sc}$ and $\mathrm{Al}-\mathrm{Cu}-\mathrm{Li}-\mathrm{Sc} 5$ series of 17 brand of al-scandium alloy products, and the first successful applications in the aerospace field. The United States, Japan, Canada, Germany and other countries have also conducted much research on scandium aluminum alloy and made great achievements. The recent development of NASA Langley research center of the brand for aluminum C557, scandium-zirconium alloy using scandium and synergistic reinforcement effects, not only improves strength and thermal stability, but also enables the alloy to work at liquid hydrogen temperatures [1-3].

In 2002, the Al-Zn-Mg-Cu-Sc alloy jointly developed by Ukraine and the United States has $\mathrm{Zn}$ $10-12 \%, \mathrm{Mg} 3 \%$, Cu 1-2\% and Sc $0.49 \%$. After T6 heat treatment, hot extrusion and solid solution treatment, the yield strength of the material at room temperature is $790 \mathrm{MPa}$, the ultimate tensile strength at room temperature is up to $820 \mathrm{MPa}$, and the elongation at room temperature is up to $5-8 \%$, which is enough to be comparable with the moderate strength of titanium alloy. In the early 1990's, China began to conduct research on Al-scandium alloys. To date, some basic research work has been carried out mainly on the influence of scandium on the structure and properties of $\mathrm{Al}-\mathrm{Mg}, \mathrm{Al}-\mathrm{Zn}-\mathrm{Mg}$ 
and $\mathrm{Al}-\mathrm{Cu}-\mathrm{Mg}-\mathrm{Fe}-\mathrm{Ni}$ alloys, as well as the influence of scandium on the recrystallization temperature. Some achievements have been made, but there is still a big gap with foreign countries [4-7].

As Al-scandium alloy has a broad applications prospect in high and new technology industries such as aviation, aerospace, naval vessel and nuclear energy, it is of great significance to develop Al-scandium alloy to accelerate the development of these high and new technology industries and improve China's international competitiveness in these high and new technology industries. In addition, China has unique resources to develop Al-scandium alloys. China is a country with large aluminum and scandium resources. It is urgent to transform scandium's resource advantages into scandium's economic and technological advantages [8-10].

To date, the biggest obstacle for the development of Al-scandium alloy in China is that the price of scandium metal is too expensive, which leads to the price of Al-scandium alloy is too high for general industrial users to accept. The possible solutions are reducing the cost of scandium extraction and the production cost of aluminum-scandium master alloy. In terms of the current situation in China, the research on scandium extraction and metallurgical process has made great progress. There are many enterprises in China that recover scandium from tungsten residue, chlorinated soot and titanium white mother liquor. The output of scandium oxide in China has become the first in the world, and the price of scandium products has been much lower than that of ten years ago. However, no major breakthrough has been made in the processing technology of Al-Sc master alloy production. There is no Al-Sc master alloy production plant in China [11-13].

In recent years, much research has been done on the preparation methods of $\mathrm{Al}-\mathrm{Sc}$ master alloys. Therefore, the research on the production technology of Al-Sc master alloy should be strengthened, and the processing technology should be simplified. It is very important to reduce the production cost of Al-Sc master alloy. Scandium is one of the essential elements for the preparation of aluminum-scandium alloy. The melting point of scandium is up to $1541^{\circ} \mathrm{C}$ and its chemical properties are active. When preparing scandium alloy containing scandium, scandium must be added in the form of master alloy. The alloy is still imported and very expensive [14-16].

Scandium was enriched from V-Ti magnetite tailings from Panzhihua area of China by magnetic separation, heavy separation and electric separation, and scandium concentrate of about $80 \mathrm{~g} / \mathrm{t}$ was obtained. Scandium concentrate was prepared into high purity scandium oxide $\left(\mathrm{Sc}_{2} \mathrm{O}_{3}\right)$ products by leaching-extraction-purification process, and scandium oxide was further prepared into anhydrous scandium chloride $\left(\mathrm{ScCl}_{3}\right)$ molten salt as the raw material for the preparation of $\mathrm{Al}-\mathrm{Sc}$ master alloy [17].

In this study, the effects of reduction temperature, scandium content of molten salt, stirring temperature and reduction time on the scandium recovery (the ratio between the experimental average and theoretical value of scandium in ingots) were investigated one-by-one by single factor. Therefore, this study can provide an important research foundation for the high-quality utilization of scandium in Sc-bearing V-Ti magnetite tailings in Panxi region of China.

\section{Materials and Methods}

\subsection{Sampling, Chemical Reagent and Equipment}

The main raw materials were aluminum ingot (Industrial purity, Southwest Aluminum (Group) Co., Ltd. Chongqing, China), magnesium ingot (Industrial purity, Southwest Aluminum (Group) Co., Ltd. Chongqing, China), scandium chloride (purity, 99.8\%), Slag removal agent (Industrial purity, Zunyi aluminum Co., Ltd. Zunyi, China), Refining agent (Industrial pure, Zunyi aluminum Co., Ltd. Zunyi, China) and Covering agent (Industrial pure, Zunyi Aluminum Co., Ltd. Zunyi, China). The impurity composition analysis of the raw materials is shown in Table 1.

$\mathrm{Al}-\mathrm{Mg}-\mathrm{Sc}$ master alloy was prepared by aluminum-magnesium thermoreduction with high-purity scandium chloride. Therefore, the selected equipment must test the process of heating, heat preservation, cooling required conditions, equipment must ensure continuous work for several hours, reliability and sensitivity to high requirements. The main equipment for experimental research are vertical shaft 
furnace $\left(\leq 1300{ }^{\circ} \mathrm{C}, \Phi 100 \mathrm{~mm} \times 240 \mathrm{~mm}, 3 \mathrm{~kW}\right.$, Shanghai Shiyan Electric Furnace Co., Ltd. Shanghai, China), vertical shaft furnace $\left(\leq 1300{ }^{\circ} \mathrm{C}, \Phi 300 \mathrm{~mm} \times 500 \mathrm{~mm}, 9 \mathrm{~kW}\right.$, Shanghai Shiyan Electric Furnace Co., Ltd. Shanghai, China), vertical shaft furnace $\left(\leq 1600{ }^{\circ} \mathrm{C}, \Phi 460 \mathrm{~mm} \times 800 \mathrm{~mm}, 30 \mathrm{~kW}\right.$, Shanghai Shiyan Electric Furnace Co., Ltd. Shanghai, China), SG-15-12 model resistance furnace $\left(\leq 1300{ }^{\circ} \mathrm{C}\right.$, $\Phi 100 \mathrm{~mm} \times 240 \mathrm{~mm}, 3 \mathrm{~kW}$, Shanghai Shiyan Electric Furnace Co., Ltd. Shanghai, China) and YHW-24 model drying box $(400 \mathrm{~mm} \times 500 \mathrm{~mm} \times 300 \mathrm{~mm}$, Southwest Chengdu Experimental Equipment Co., Ltd. Chengdu, China).

Table 1. Impurity composition of raw materials.

\begin{tabular}{cccccc}
\hline \multirow{2}{*}{ Raw Materials } & \multicolumn{5}{c}{ Composition (\%) } \\
\cline { 2 - 6 } & Fe & Si & Ca & $\mathbf{P}$ & Ti \\
\hline Aluminum ingot & 0.126 & 0.684 & 0.045 & 0.001 & 0.059 \\
Magnesium ingot & 0.062 & 0.027 & 0.019 & 0.001 & 0.068 \\
Scandium chloride & 0.015 & 0.062 & 0.034 & 0.003 & 0.012 \\
Slag removal agent & 0.033 & 0.044 & 0.018 & 0.004 & 0.031 \\
Refining agent & 0.061 & 0.145 & 0.017 & 0.003 & 0.049 \\
Covering agent & 0.038 & 0.275 & 0.021 & 0.002 & 0.026 \\
\hline
\end{tabular}

\subsection{Procedure}

Aluminum, magnesium and anhydrous scandium chloride molten salt were measured according to the required ingredients, and then appropriate covering agent, slag cleaner and refining agent were taken. Put them all into the drying oven and heat them to dry at a temperature of not less than $373 \mathrm{~K}$. The graphite crucible is then placed in a resistance furnace. Around $773 \mathrm{~K}$ heating furnace on heating up, when to take out the graphite crucible, the aluminum and magnesium into the graphite crucible, back into the resistance furnace heating up, at the same time into the furnace in the argon gas protection, temperature to $1023 \mathrm{~K}$ heat preservation, after waiting for aluminum and magnesium melting, stir and add right amount covering agent, continue to heat up to the reduction temperature, adding anhydrous scandium chloride molten salt, mixing reaction after a period of time, temperature will be dispatched to the pouring temperature, in addition to gas slag refining agent, and adding suitable amount of cover agent and slag removal agent, mixed grilled slag, casting. The process of preparing Sc-bearing master alloy is shown in Figure 1.

The chemical composition of solid materials was analyzed by a Z-2000 atomic absorption spectrophotometer (Hitachi Co., Ltd. Tokyo, Japan); the direction grating was Zenier-tana type, 1800 lines/mm; the flash wavelength was $200 \mathrm{~nm}$, the wavelength range was 190-900 nm; and the automatic peak seeking setting and the spectral bandwidth was divided into 4 grades $(0.2,0.4,1.3$ and $2.6 \mathrm{~nm}$ ) to analyze the chemical composition of the mineral.

The scandium recovery rate is calculated by analyzing the scandium content in Al-Sc master alloy. The scandium content of the alloy ingots is analyzed at 5 points ( $a$-top left corner, $b$-top right corner, c-bottom left corner, $\mathrm{d}$-bottom right corner and e-center).

The arithmetic average of five points is the scandium content of the alloy ingots. The calculation formula of scandium recovery is shown in Equations (1) and (2).

$$
\begin{gathered}
\beta=(\beta \mathrm{a}+\beta \mathrm{b}+\beta \mathrm{c}+\beta \mathrm{d}+\beta \mathrm{e}) / 5 \\
\text { scandium recovery }=\left(\mathrm{Q}_{1} \times \beta\right) /\left(\mathrm{Q}_{0} \times \beta_{0}\right) \times 100 \%
\end{gathered}
$$

where $Q_{1}$ is the weight of Sc-bearing master alloy ingot casting $/ g, Q_{0}$ is the weight of anhydrous scandium chloride $/ g, \beta$ is the average scandium content in Sc-bearing master alloy ingot casting $/ \%$, $\beta_{\mathrm{a}}$ is the scandium content of position a in Sc-bearing master alloy ingot casting $/ \%, \beta_{\mathrm{b}}$ is the scandium content of position $\mathrm{b}$ in Sc-bearing master alloy ingot casting $/ \%, \beta_{\mathrm{c}}$ is scandium content of position $\mathrm{c}$ in Sc-bearing master alloy ingot casting $/ \%, \beta_{\mathrm{d}}$ is the scandium content of position $\mathrm{d}$ in Sc-bearing 
master alloy ingot casting $/ \%, \beta_{\mathrm{e}}$ is the scandium content of position e in Sc-bearing master alloy ingot casting $/ \%, \beta_{0}$ is the scandium content in scandium chloride molten salt $/ \%$.

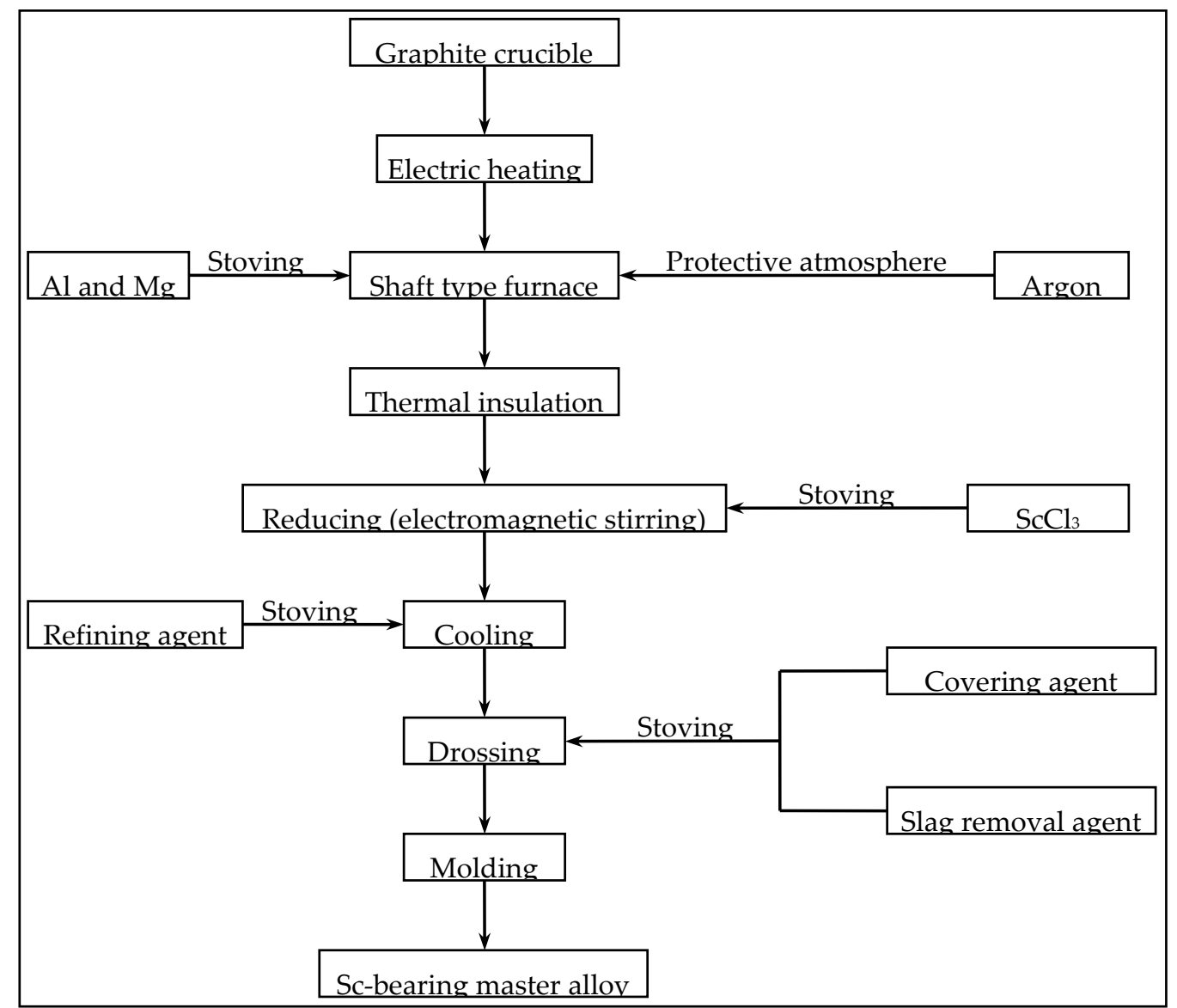

Figure 1. Scheme of preparing Sc-bearing master alloy.

\section{Results and Discussion}

\subsection{Thermodynamic Calculation of Reduction Reactions}

The Gibbs free energy and equilibrium constant of the reduction reaction of sodium, calcium, magnesium, aluminum, and scandium chloride at different temperatures were calculated, respectively. The relation curve between the equilibrium constant and temperature is shown in Figure 2 (Curve 1-4). The results show that sodium, calcium and magnesium can reduce scandium chloride. Since Na and $\mathrm{Ca}$ are expensive and have adverse effects on the properties of aluminum alloys, and $\mathrm{Mg}$ is the main alloy component of many aluminum alloys.

It is most suitable to prepare scandium master alloy with $\mathrm{Mg}$ as reducing agent. Aluminum cannot reduce scandium chloride to scandium metal and can only be reduced to $\mathrm{ScCl}_{2}$. However, aluminum can generate stable intermetallic compounds with scandium. When reducing scandium chloride with magnesium, adding aluminum can promote the reduction reaction. Under the appropriate molten salt system and reduction conditions, scandium chloride is reduced by magnesium to scandium metal, scandium metal and magnesium are mutually soluble, and aluminum and scandium form stable intermetallic compounds [18]. The reduction reaction can be expressed as Equations (3)-(5):

$$
\begin{gathered}
2 \mathrm{ScCl}_{3}+3 \mathrm{Mg}=2 \mathrm{Sc}+3 \mathrm{MgCl}_{2} \\
\mathrm{Sc}+3 \mathrm{Al}=\mathrm{Al}_{3} \mathrm{Sc}
\end{gathered}
$$




$$
2 \mathrm{ScCl}_{3}+3 \mathrm{Mg}+6 \mathrm{Al}=3 \mathrm{MgCl}_{2}+2 \mathrm{Al}_{3} \mathrm{Sc}
$$

According to the relevant thermodynamic data and the calculation of standard enthalpy of formation of $\mathrm{Al}_{3} \mathrm{Sc}$, the above reduction reaction equilibrium constant changes with temperature as shown in Figure 2 (Curve 5). Due to the formation of $\mathrm{Al}_{3} \mathrm{Sc}$ compounds, the reduction reaction equilibrium constant increases by more than 30 times at $1100 \mathrm{~K}$.



Figure 2. Equilibrium constant calculated at metallic thermoreduction temperature.

At $1200 \mathrm{~K}, 1$ atmosphere, the Gibbs free energy of this reaction changes [19]:

$$
\begin{aligned}
\Delta G_{(5)}^{0}(1200 \mathrm{~K}) & =2 \Delta G^{0}\left(\mathrm{Al}_{3} \mathrm{Sc}\right)+3 \Delta G^{0}\left(\mathrm{MgCl}_{2}\right)-2 \Delta G^{0}\left(\mathrm{ScCl}_{3}\right)=2 \times(-128)+3 \times \\
& (-459.987)-2 \times(-649.385)+-437.19 \mathrm{KJ} / \mathrm{mol}<0
\end{aligned}
$$

The standard equilibrium constant $\mathrm{K}=1.094 \times 10^{3}$ is calculated by $\Delta \mathrm{G}=-\mathrm{RT} \ln K$. At $1200 \mathrm{~K}$, 1 standard atmospheric pressure, the Gibbs free energy change of $\mathrm{Mg}$ and $\mathrm{Al}$ reduced-scandium chloride reaction $\Delta \mathrm{G}_{(5)}^{0}(1200 \mathrm{~K})=-437.19 \mathrm{KJ} / \mathrm{mol}<0$ and the standard equilibrium constant $K=1.094 \times 10^{3}$. This shows that in a pure state of matter the reaction can be done at $1200 \mathrm{~K}$, and it can be done very thoroughly. This indicates that the reduction of scandium chloride by aluminum-magnesium is more feasible. At the same time, it also indicates that in the process of reduction of scandium chloride by aluminum-magnesium, both aluminum and magnesium participate in the reaction. Magnesium mainly plays the reduction role, while aluminum mainly plays the role of capture, and $\mathrm{Al}_{3} \mathrm{Sc}$ is generated by alloying reaction with the generated scandium, which promotes the reduction reaction.

\subsection{Small Test of Preparing Al-Mg-Sc Master Alloy}

\subsubsection{Effect of Reduction Temperature}

The thermodynamic calculation results in Figure 1 show that the equilibrium constant of reduction reaction decreases with the increase of temperature, and the equilibrium constant basically remains unchanged in the range of $900-1200 \mathrm{~K}$. However, when the temperature is too low, the reduction reaction may be in the solid-solid or solid-liquid interface, which is not conducive to the reduction reaction. Therefore, the reaction temperature should be appropriately raised, and the appropriate molten salt system should be selected to promote the reduction reaction.

The low reduction temperature and high viscosity of molten salt solution are not conducive to the diffusion of reaction ions and the reaction speed is slow. However, too high reduction temperature also has many adverse effects. As the reduction reaction is exothermic, the high temperature affects the progress of the reaction. In addition, the evaporation loss of molten salt solution is serious when the 
temperature is high. Therefore, an optimal temperature selected will be beneficial for improving the product quality of $\mathrm{Al}-\mathrm{Mg}-\mathrm{Sc}$ master alloy.

Results in Figure 3 show that when the reduction temperature was lower than $1223 \mathrm{~K}$, the recovery rate of scandium increased with the increase of reduction temperature. When the temperature rose to $1223 \mathrm{~K}$, the recovery of scandium reached a maximum of $88.33 \%$. However, when the temperature increased to $1273 \mathrm{~K}$, the recovery rate of scandium decreased to $84.33 \%$.The main reasons for this change are: when the reduction temperature is lower than $1223 \mathrm{~K}$, the low reduction temperature and high viscosity of molten salt solution are unfavorable for the diffusion of reaction ions, and the reaction speed is slow. The reduction temperature is higher than $1223 \mathrm{~K}$, the reaction progress is reduced, and the molten salt volatilization is serious due to the high temperature, resulting in the decrease of scandium recovery. Therefore, a reduction temperature of $1223 \mathrm{~K}$ was suitable. The scandium-bearing master with a scandium average content $2.53 \%$ and scandium recovery of $84.33 \%$ was obtained.

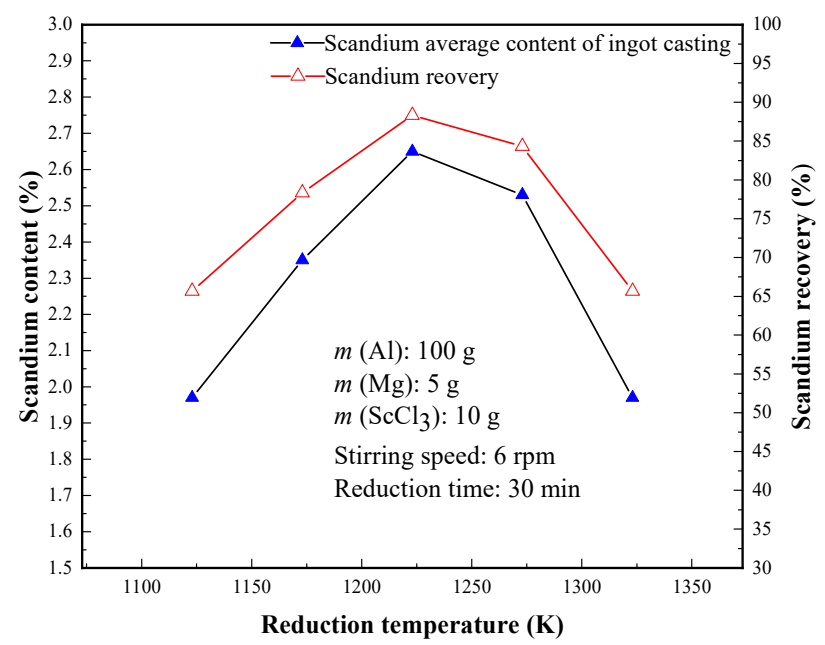

Figure 3. Effect of reduction temperature on scandium content and recovery of Sc-bearing master alloy ingot casting.

\subsubsection{Effect of $\mathrm{ScCl}_{3}$ Molten Salt Dosage}

Because this test is prepared by aluminum-magnesium thermally reducing scandium chloride molten salt method. Therefore, the viscosity of the molten state of the anhydrous scandium chloride molten salt has a great influence on the thermal reduction reaction, and the viscosity of the molten state of the molten salt is related to the level of scandium dosage, in addition, and also affects the reaction speed and the degree of the reaction. For this purpose, high-purity anhydrous scandium chloride molten salt dosage on indicator of Sc-bearing master alloys should be tested to determine the best scandium molten salt dosage, and the results are shown in Figure 4.

The results in Figure 4 reveal that with the increase of high-purity anhydrous scandium chloride molten salt dosage, scandium recovery also will increase, in the experiment found that at this time of molten salt liquid thin, this shows that in the molten salt dosage was less than $10 \mathrm{~g}$, the dosage of scandium chloride molten salt plays a leading role, with the increase of scandium chloride dosage, reduction reaction speed and schedule of scandium recovery increased. When anhydrous scandium chloride molten salt was $15 \mathrm{~g}$, the scandium content scandium recovery of Sc-bearing master alloy were $2.77 \%$ and $92.33 \%$, respectively. The high-purity anhydrous scandium chloride molten salt dosage exceeds $15 \mathrm{~g}$, the scandium recovery began to decrease gradually. Therefore, high-purity anhydrous scandium chloride molten salt dosage of $15 \mathrm{~g}$ was an optimal dosage. 


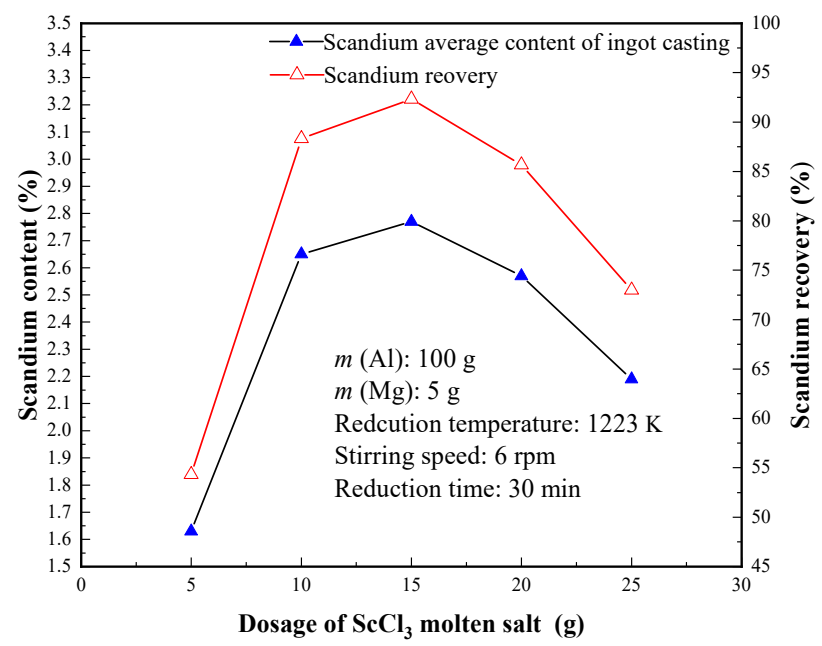

Figure 4. Effect of $\mathrm{ScCl}_{3}$ molten salt dosage on scandium content and recovery of Sc-bearing master alloy ingot casting.

\subsubsection{Effect of Stirring Speed (Rotation per Minute)}

The thermal reduction reaction between scandium chloride and aluminum-magnesium alloy is a liquid-liquid reaction, which can only be carried out at the interface. Stirring can make the reactants fully contact, increase the chance of reactants colliding and products leaving and strengthen the reaction. However, excessive stirring increases the chance of exposing the alloy to the air and oxidizes the alloy, resulting in the reduction of scandium recovery. For this reason, stirring speed test is needed to determine the appropriate stirring strength.

It is known from the results in Figure 5 that the stirring speed were less than $6 \mathrm{rpm}$, the scandium recovery increased gradually with the increasing of stirring times. When the stirring times increased from 6 to $8 \mathrm{rpm}$, the scandium recovery rate was basically unchanged. However, when the stirring times increased to $10 \mathrm{rpm}$, the scandium recovery decreased slightly. This indicates that moderate stirring can greatly promote the reduction reaction and improve the scandium recovery. If the stirring frequency is too much, the scandium recovery will decrease due to the oxidation of the alloy liquid. Therefore, the number of stirring determined in the stirring speed of $8 \mathrm{rpm}$ was an optimal condition.



Figure 5. Effect of stirring speed on scandium content and recovery of Sc-bearing master alloy ingot casting. 


\subsubsection{Effect of Reduction Time}

Effect of reduction time scandium content and recovery of Sc-bearing master alloy ingot casting was shown in Figure 6. Reduction time has a significant influence on scandium recovery, with the increase of reduction time, the scandium recovery appears a regular change of first increasing and then decreasing. When the reduction time reached $40 \mathrm{~min}$, the scandium content of Sc-bearing master alloy ingot casting and scandium recovery decreased to $2.66 \%$ and $88.67 \%$, respectively. Therefore, Sc-bearing master alloy with a scandium average content $2.85 \%$ and scandium recovery of $95.00 \%$ was under the optimal reduction time of $40 \mathrm{~min}$.

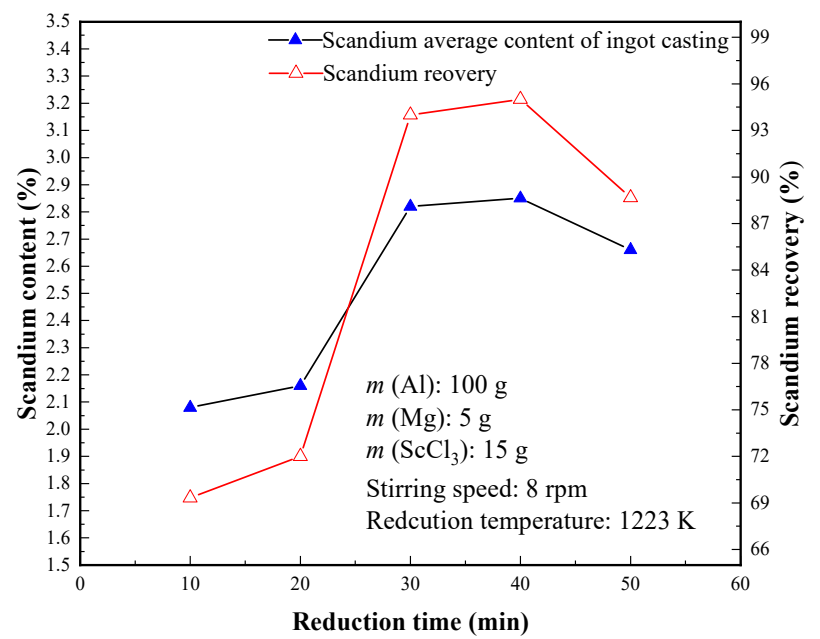

Figure 6. Effect of reduction time on scandium content and recovery of Sc-bearing master alloy ingot casting.

\subsubsection{Effect of Mg Dosage}

Effect of Mg dosage on scandium content and recovery of Sc-bearing master alloy ingot casting was shown in Figure 7. The scandium average content in alloy ingots and the scandium recovery were improved by increasing the dosage of magnesium. When the magnesium dosage increased to $10 \mathrm{~g}$, the average scandium content in alloy ingot was $2.89 \%$, and the scandium recovery was $96.33 \%$. When the amount of magnesium exceeds $10 \mathrm{~g}$, the average content and recovery of scandium in alloy ingots decrease to a certain extent. It shows that the magnesium dosage of $10 \mathrm{~g}$ was more suitable for improve the quality of Sc-bearing master alloy.

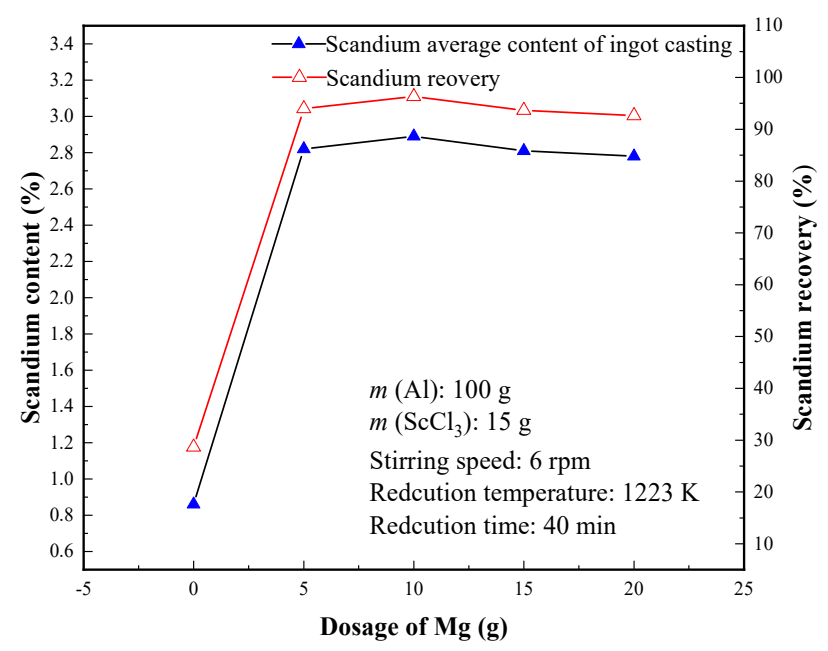

Figure 7. Effect of $\mathrm{Mg}$ dosage on scandium content and recovery of Sc-bearing master alloy ingot casting. 


\subsubsection{Repeated Test}

In order to verify the reliability and stability of the small-scale test process conditions, 6 comprehensive tests were carried out under the conditions used: $m(\mathrm{Al})=100 \mathrm{~g}, m(\mathrm{Mg})=5 \mathrm{~g}$, $m\left(\mathrm{ScCl}_{3}\right)=15 \mathrm{~g}$, stirring speed of $8 \mathrm{rpm}$, reduction temperature of $1223 \mathrm{~K}$, reduction time of $40 \mathrm{~min}$. The test results were shown in Table 2.

Table 2. Results of comprehensive conditions repeated tests.

\begin{tabular}{ccc}
\hline Repeat & $\begin{array}{c}\text { Average scandium Content in } \\
\text { Ingot Casting (g) }\end{array}$ & Scandium Recovery (\%) \\
\hline 1 & 2.86 & 95.33 \\
2 & 2.84 & 94.66 \\
3 & 2.93 & 97.66 \\
4 & 2.92 & 97.33 \\
5 & 2.89 & 96.33 \\
6 & 2.88 & 96.00 \\
Average & 2.89 & 96.22 \\
Arithmetic mean error $\left(\delta=\frac{\sum_{i=1}^{N}\left|d_{i}\right|}{N}\right)$ & 0.09 & 3.00 \\
Sum square variation & 0.027 & 0.89 \\
$\left(S S=\sum_{i=1}^{N} d_{i}^{2}=\sum_{i=1}^{N}\left(E_{i}-\bar{E}\right)^{2}\right)$ & & 6.59 \\
Average deviation $\left(M S=\frac{S S}{f}\right)$ & 0.006 & 1.32 \\
Standard deviation & 0.001 & 1.15 \\
$\left(s=\sqrt{\left.\frac{\sum\left(E_{i}-\bar{E}\right)^{2}}{N-1}=\sqrt{M S}\right)}\right.$ & 0.032 & \\
\hline
\end{tabular}

It is known from Table 2 that the Al-Mg-Sc master alloy with scandium content of $2.89 \%$, scandium recovery of $96.22 \%$ was produced. Scandium content and scandium recovery indices fluctuated little, which indicated that the test was stable, and the process conditions were reliable.

\subsection{Scandium Segregation Analysis of Small Test Ingot Castings}

There are three main stages in the separation of refractory dissolved metals. In the second stage, the nucleus grows by various means of material transport (Diffusion, Ostwald maturation, Marangoni movement, Convection, etc.), and is coarsened by collisions between nuclei. In the third stage, when the droplets reach a certain size, the droplets of the second phase begin to deposit or float under the action of the component density difference and the Marangoni movement. During the movement, the droplets of smaller size are constantly captured, resulting in coagulation and finally resulting in the volume stratification [20-24].

Therefore, there are two kinds of methods to control the segregation of elements in the melting process. The second kind is from the kinetic consideration, the melting is treated fast. The third stage is too late to proceed, the second stage is incomplete. In the previous test, the alloy ingots (with a thickness of about $20 \mathrm{~mm}$ ) from 5 of the tests were sampled and analyzed to investigate the segregation of scandium. Three alloy ingots were taken for each sample, and the sampling locations were upper, lower and middle. The analysis results are shown in Table 3.

The scandium content in the lower part of the alloy ingots is obviously higher than that in the upper part, that is, scandium is more segregated in the longitudinal direction of the alloy ingots, but the average scandium content in the upper and lower parts is almost the same as that in the middle part, which is basically consistent. This indicates that from the lower part of the ingot to the upper part, the scandium content is basically uniformly reduced. 
Table 3. Different sampling scandium content analysis in alloy ingots.

\begin{tabular}{cccccc}
\hline \multirow{2}{*}{ Number } & \multicolumn{3}{c}{ Scandium Content (\%) } & Average Value & $\begin{array}{c}\text { Scandium } \\
\text { Recovery (\%) }\end{array}$ \\
\cline { 2 - 4 } & Top (A) & Lower (B) & Middle (C) & betwen A and B & 2.27 \\
\hline 1 & 2.56 & 4.26 & 2.68 & 2.46 & 98.08 \\
2 & 2.27 & 3.75 & 2.76 & 2.51 & 93.67 \\
3 & 2.31 & 3.89 & 2.61 & 2.71 & 96.33 \\
4 & 1.96 & 4.05 & 2.85 & 2.19 & 92.42 \\
5 & 2.11 & 4.23 & 2.56 & 2.43 & 94.98 \\
\hline
\end{tabular}

\subsection{Scale-Up Test and Scandium Segregation Analysis in Ingot Castings}

After the preparation of Al-Sc master alloy with anhydrous scandium chloride molten salt, the ideal intermediate alloy index was obtained. Therefore, the conditions were optimized to reduce segregation during the expansion test, and the quality of the alloy was further analyzed. On the basis of the small-scale test, the scale of the test was expanded to $1000 \mathrm{~g}$ per furnace charge, and four tests were carried out to verify whether the process conditions determined by the small-scale test can meet the requirements of the enlarged test. The scale-up test conditions used: the ration of $m(\mathrm{Al}): m(\mathrm{Mg})$ : $m\left(\mathrm{ScCl}_{3}\right)=10: 1: 1.5$, stirring speed of $8 \mathrm{rpm}$, reduction temperature of $1223 \mathrm{~K}$, reduction time of $40 \mathrm{~min}$.

In scale-up tests, three of the four trials alloy ingot (about $20 \mathrm{~mm}$ thick) sampling analysis, investigating the segregation of scandium, each alloy ingot sample 5, sample code and sampling site shows as follows: A-, B-, C-from alloy ingot center drilled above to below, D-since the alloy ingot end drill down to the following above, E-since the alloy ingot above drill down to the other end, the analysis results were shown in Table 4.

Table 4. Different sampling position analysis results of scale-up test alloy ingots.

\begin{tabular}{cccccccc}
\hline \multirow{2}{*}{ Number } & \multicolumn{8}{c}{ Scandium Content (\%) } & Scandium Recovery (\%) \\
\cline { 2 - 7 } & A & B & C & D & E & Average between A and B & 78.20 \\
\hline 1 & 1.76 & 2.06 & 2.53 & 2.69 & 2.69 & 1.91 & 79.80 \\
2 & 1.66 & 2.19 & 2.66 & 2.77 & 2.69 & 1.93 & 79.00 \\
3 & 1.57 & 2.25 & 2.47 & 2.88 & 2.68 & 1.91 & 75.07 \\
4 & 1.97 & 2.06 & 2.36 & 2.54 & 2.33 & 2.02 & 75.73 \\
Average & 1.27 & 2.24 & 2.51 & 2.77 & 2.57 & 1.76 & \\
\hline
\end{tabular}

The scandium content in the lower part of the ingot (sample B) is still much higher than that in the upper part (sample A), that is, the segregation of scandium in the longitudinal direction of the ingot is still large. However, the scandium content of the three samples (C, D and E) drilled from the top of the alloy ingots to the bottom of the three samples (C, D and E) is not much different and basically stable, and is basically consistent with the average scandium content of the upper and lower parts of the alloy ingots, which indicates that scandium segregation in the transverse part of the alloy ingots is not large, and scandium segregation is mainly concentrated in the longitudinal part of the alloy ingots.

After careful analysis and research, we believe that the reason for the poor results after the expansion of the experiment is insufficient stirring by hand, because after the expansion of the experiment, the thickness of the metal liquid and molten salt liquid in the graphite crucible increased, and manual stirring with a stirring rod could not make the two liquid phases fully contact, resulting in poor results of the expansion experiment. To solve the problem of insufficient manual stirring, a new stirring method is needed.

\section{(1) Stirring by Blowing Argon Method}

As the stirring conditions determined by the small-scale experiment cannot meet the requirements of the expanded experiment, a new stirring method is needed to strengthen the stirring. In the smelting 
of alloy, argon blowing method is often used to refine the alloy liquid to remove the hydrogen and oxide slag. Since argon blowing method can be used to refine the alloy liquid, its stirring effect must be very good. For this reason, we decided to try the experiment of argon blowing and stirring. If this method is feasible, it can not only achieve the stirring effect, but also refine the alloy liquid. Effect of stirring by blowing argon method was shown in Table 5 .

Table 5. Effect of stirring by blowing-argon method on scandium content and recovery of Sc-bearing master alloy ingot casting.

\begin{tabular}{|c|c|c|c|c|c|c|c|}
\hline \multirow{2}{*}{ Number } & \multicolumn{6}{|c|}{ Scandium Content (\%) } & \multirow{2}{*}{ Scandium Recovery (\%) } \\
\hline & A & B & $\mathrm{C}$ & D & E & Average between $A$ and $B$ & \\
\hline 1 & 1.94 & 3.03 & 2.66 & 2.52 & 2.74 & 2.49 & 85.93 \\
\hline 2 & 1.89 & 3.17 & 2.62 & 2.79 & 2.81 & 2.53 & 88.53 \\
\hline 3 & 1.92 & 3.26 & 2.57 & 2.78 & 2.82 & 2.59 & 89.00 \\
\hline 4 & 1.87 & 2.98 & 2.66 & 2.59 & 2.79 & 2.43 & 85.93 \\
\hline Average & 1.91 & 3.11 & 2.63 & 2.67 & 2.79 & 2.51 & 85.93 \\
\hline
\end{tabular}

The results in Table 5 show that the scandium recovery in the expanded experiment was obviously increased by argon blowing method, which indicated that this method was effective. However, compared with small experiments, scandium yield is still low. In order to increase the contact between molten salt and Al-Mg alloy liquid, we improved the way of molten salt adding.

\section{(2) $\mathrm{ScCl}_{3}$ Molten Salt Bell Jar by Argon Stirring Method}

In the previous experiments, the anhydrous scandium chloride molten salt was directly added to the surface of the Al-Mg alloy liquid, which could not make the molten salt and Al-Mg alloy liquid fully contact. By pressing molten salt into Al-Mg alloy liquid with bell jar, the contact between molten salt and Al-Mg alloy liquid can be increased, and the reduction reaction can be carried out effectively. Therefore, we decided to conduct the experiment by combining molten salt bell jar with argon blowing and stirring method. The bell jar was used to press molten salt into the alloy liquid. It was required that the loading amount should not be too small, otherwise the bell jar could not be immersed, so the loading amount was expanded to $2 \mathrm{~kg}$. Effect of $\mathrm{ScCl}_{3}$ molten salt bell Jar by Argon Stirring Method was shown in Table 6.

Table 6. Results of $\mathrm{ScCl}_{3}$ molten salt bell jar by argon stirring method.

\begin{tabular}{cccccccc}
\hline \multirow{2}{*}{ Number } & \multicolumn{8}{c}{ Scandium Content (\%) } & Scandium Recovery (\%) \\
\cline { 2 - 7 } & A & B & C & D & E & Average between A and B & 97.53 \\
\hline 1 & 2.76 & 3.26 & 2.93 & 2.79 & 2.89 & 3.01 & 96.47 \\
2 & 2.66 & 3.12 & 2.86 & 2.87 & 2.96 & 2.89 & 96.33 \\
3 & 2.57 & 3.15 & 2.89 & 2.92 & 2.92 & 2.86 & 96.80 \\
4 & 2.68 & 3.26 & 2.66 & 2.98 & 2.94 & 2.97 & 96.78 \\
Average & 2.67 & 3.20 & 2.84 & 2.89 & 2.93 & 2.93 & \\
\hline
\end{tabular}

The experiment results in Table 6 confirm that molten salt bell jar with argon gas mixing method was very good, and the scandium recovery reached to $96.78 \%$, slightly higher than scandium recovery in small experiments of $94.98 \%$, indicating that the molten salt bell jar with argon gas mixing method was effective.

\subsection{Middle Test of Preparing Al-Mg-Sc Master Alloy}

Based on small trials and expanding process conditions were stirring speed of $8 \mathrm{rpm}$, reduction temperature of $1223 \mathrm{~K}$, reduction time of $40 \mathrm{~min}$. Ratio of raw material weight (metal) as follows: 
$m(\mathrm{Al}): m(\mathrm{Mg}): m\left(\mathrm{ScCl}_{3}\right)=10: 1: 1.5$. After test casting alloy ingot has two pieces, the first block weighs $1.684 \mathrm{~kg}$, the second block weighs $2.769 \mathrm{~kg}$, the third block of $3.564 \mathrm{~kg}$, the total weight of $8.017 \mathrm{~kg}$ (due to press the bell into molten salt, splash liquid alloy is more, grilled slag when pulled out more alloy liquid, plus graphite crucible melt in this test, leak more alloy liquid, so finally casting alloy ingot less). The test results of scandium and magnesium content in ingot are shown in Table 7, and the test results of impurity element content are shown in Table 8.

Table 7. Analysis results of pouring alloy ingots.

\begin{tabular}{ccccc}
\hline \multirow{2}{*}{ Alloy Ingots } & \multirow{2}{*}{ Position } & \multicolumn{2}{c}{ Content (\%) } & \multirow{2}{*}{ Scandium Recovery (\%) } \\
\cline { 3 - 4 } & & Sc & Mg & \\
\hline \multirow{2}{*}{ First } & Top & 2.68 & 6.12 & \multirow{2}{*}{97.17} \\
& Lower & 3.15 & 5.44 & \multirow{2}{*}{ Second } \\
& Top & 2.37 & 6.25 & \multirow{2}{*}{96.33} \\
& Lower & 3.41 & 5.26 & 96.67 \\
\hline \multirow{2}{*}{ Third } & Top & 2.51 & 4.96 & 96.72 \\
\hline
\end{tabular}

Table 8. Impurity composition analysis results of pouring alloy ingots.

\begin{tabular}{cccccccc}
\hline \multirow{2}{*}{ Alloy Ingots } & \multirow{2}{*}{ Position } & \multicolumn{7}{c}{ Content (\%) } \\
\cline { 3 - 8 } & & $\mathbf{C u}$ & $\mathbf{S i}$ & $\mathbf{T i}$ & $\mathbf{F e}$ & $\mathbf{Z n}$ & $\mathbf{N a}$ \\
\hline \multirow{2}{*}{ First } & Top & 0.0052 & 0.25 & 0.033 & 0.14 & 0.0067 & 0.0027 \\
& Lower & 0.0061 & 0.29 & 0.025 & 0.13 & 0.0079 & 0.0019 \\
\hline \multirow{2}{*}{ Second } & Top & 0.0054 & 0.31 & 0.028 & 0.15 & 0.0088 & 0.0022 \\
& Lower & 0.0059 & 0.28 & 0.027 & 0.12 & 0.0076 & 0.0029 \\
\hline \multirow{2}{*}{ Third } & Top & 0.0058 & 0.32 & 0.031 & 0.11 & 0.0069 & 0.0025 \\
& Lower & 0.0063 & 0.28 & 0.029 & 0.15 & 0.0072 & 0.0026 \\
\hline \multicolumn{2}{c}{ Average } & 0.0058 & 0.29 & 0.029 & 0.13 & 0.0075 & 0.0025 \\
\hline
\end{tabular}

It can be seen from Tables 7 and 8 that the three alloy ingots contain an average of $2.90 \%$ scandium, an average of $5.73 \%$ magnesium, and the recovery rate of scandium was $96.72 \%$. Magnesium is evenly distributed and segregation is small in ingots, but scandium is more segregation in ingots. On average, the three alloy ingots contained $0.0058 \% \mathrm{Cu}, 0.29 \% \mathrm{Si}, 0.029 \% \mathrm{Ti}, 0.13 \% \mathrm{Fe}, 0.075 \% \mathrm{Zn}$ and $0.025 \% \mathrm{Na}$. The content of impurity elements $\mathrm{Si}$ and Fe is slightly higher, which may be due to the slightly higher content of the two impurity elements in the raw material, while the content of other impurity elements is relatively low. The standard of Al-Sc intermediate ingot has not been established, but according to the impurity requirements of YS/T 282-2000 "Al master ingot", the content of impurity elements in ingot is not high. Generally speaking, the intermediate test has obtained good indices, the three alloy ingots have an average scandium content of $2.90 \%$ and an average magnesium content of $5.73 \%$, the scandium recovery is $96.72 \%$, and the content of each impurity element is relatively low.

\section{Conclusions}

Based on the results obtained in this work, we drew the following conclusions:

(1) Thermodynamic calculations show that $\mathrm{ScCl}_{3}$ can be reduced by magnesium to scandium metal at $1000-1200 \mathrm{~K}$-and when aluminum exists, the equilibrium concentration of $\mathrm{ScCl}_{3}$ can be greatly reduced to the formation of $\mathrm{Al}_{3} \mathrm{Sc}$ compound;

(2) The small test results of preparing Sc-bearing master alloy show that Sc-bearing master alloy with scandium content of $2.89 \%$, and scandium recovery of $96.22 \%$ was obtained under the 
technological conditions used: $m(\mathrm{Al}): m(\mathrm{Mg}): m\left(\mathrm{ScCl}_{3}\right)=10: 1: 1.5$, stirring speed of eight $\mathrm{rpm}$, reduction temperature of $1223 \mathrm{~K}$, reduction time of $40 \mathrm{~min}$;

(3) Because the process conditions determined by the small-scale test could not meet the requirements of the expanded test, the expanded test optimized the process conditions determined by the small-scale test, changed the stirring mode to argon blowing stirring, changed the molten salt adding mode to bell jar pressing, and finally determined the process conditions for the preparation of aluminum, magnesium and scandium intermediate alloy. The scandium recovery of $\mathrm{Al}-\mathrm{Mg}-\mathrm{Sc}$ master alloy reached to $96.78 \%$, which was basically superior to the index of small scale test;

(4) Under the intermediate alloy, the process conditions were determined, which was carried out among $10 \mathrm{~kg}$ level preparation of Al-Mg-Sc master alloy test. The Al-Mg-Sc master alloy ingot contained $2.90 \% \mathrm{Sc}, 5.73 \% \mathrm{Mg}, 0.0058 \% \mathrm{Cu}, 0.29 \%, 0.029 \% \mathrm{Ti}, 0.13 \% \mathrm{Fe}, 0.075 \% \mathrm{Zn}, 0.025 \% \mathrm{Na}$, and $96.72 \%$ recovered scandium. The main content of impurity elements are lower and $\mathrm{Al}-\mathrm{Mg}-\mathrm{Sc}$ master alloy indicator was ideal. The scandium recovery approaches to $100 \%$, and the preparation of Sc-bearing master alloy by this method is simple and can reduce the production cost greatly.

Author Contributions: This is a joint work of the five authors; each author was in charge of their expertise and capability: J.X.: writing, formal analysis, original draft preparation and investigation; W.D.: conceptualization; Y.P.: validation; T.C. and K.Z.: methodology. All authors have read and agreed to the published version of the manuscript.

Funding: This work was supported by the Sichuan Science and Technology Program (Grant Nos.2018FZ0092, Nos.2019FS0451 and Nos.2019FS0452); China Geological Big Survey (Grant No. DD20190694); Key Laboratory of Sichuan Province for Comprehensive Utilization of Vanadium and Titanium Resources Foundation (2018FTSZ35).

Conflicts of Interest: The authors declare no conflict of interest. The funders had no role in the design, analyses and interpretation of any data of the study.

\section{References}

1. Bian, M.Z.; Huang, X.S.; Mabuchi, M.; Chino, Y. Compositional optimization of Mg-Zn-Sc sheet alloys for enhanced room temperature stretch formability. J. Alloys Compd. 2020, 818, 152891. [CrossRef]

2. Fujii, S.S.; Suzuki, E.C.; Inazu, N.M.; Tsubaki, S.T.; Fukushima, J.; Takizawa, H.S.; Wada, Y.J. Microwave irradiation process for Al-Sc alloy production. Sci. Rep. 2020, 10, 2689. [CrossRef] [PubMed]

3. Ryabtsev, S.I.; Polonskyy, V.A.; Sukhova, O.V. Effect of scandium on the structure and corrosion properties of vapor-deposited nanostructured quasicrystalline Al-Cu-Fe films. Powder Metall. Met. Ceram. 2020, 58, 567-575. [CrossRef]

4. Ganiev, I.N.; Norova, M.T.; Eshov, B.B.; Ibrokhimov, N.F.; Ibrokhimov, S.Z. Effect of scandium additions on the temperature dependences of the heat capacity and thermodynamic functions of aluminum-manganese alloys. Phys. Met. Metallogr. 2020, 121, 21-27. [CrossRef]

5. Coy, M.; Russell, K.; Heidelberger, E.; Sanders, P.; Langan, T. Effect of scandium on cast iron microstructure. Int. J. Metalcast. 2020, 14, 275-277. [CrossRef]

6. Khrustalyov, A.P.; Kozulin, A.A.; Zhukov, I.A.; Khmeleva, M.G.; Vorozhtsov, A.B.; Eskin, D.; Chankitmunkong, S.; Platov, V.V.; Vasilyev, S.V. Influence of titanium diboride particle size on structure and mechanical properties of an Al-Mg Alloy. Metals 2019, 10, 1030. [CrossRef]

7. Liu, L.; Jia, Y.Y.; Jiang, J.T.; Zhang, B.; Li, G.A.; Shao, W.Z.; Zhen, L. The effect of Cu and Sc on the localized corrosion resistance of Al-Zn-Mg-X alloys. J. Alloys Compd. 2019, 799, 1-14. [CrossRef]

8. Guo, Z.C.; Liu, X.; Xue, J.L. Fabrication of Al-Si-Sc alloy bearing $\mathrm{AlSi}_{2} \mathrm{Sc}_{2}$ phase using ultrasonically assisted molten salt electrolysis. J. Alloys Compd. 2019, 797, 883-889. [CrossRef]

9. Dorin, T.; Ramajayam, M.; Babaniaris, S.; Langan, T.J. Micro-segregation and precipitates in as-solidified Al-Sc-Zr-(Mg)-(Si)-(Cu) alloys. Mater. Charact. 2019, 154, 353-362. [CrossRef]

10. Ali, S.R.A.S.; Hussein, A.H.A.; Nofal, A.; Elnaby, S.I.H.; Elgazzar, H. A contribution to laser cladding of Ti-6Al-4V titanium alloy. Metall. Res. Technol. 2019, 116, 634.

11. Rogachev, S.O.; Naumova, E.A.; Sundeev, R.V.; Tabachkova, N.Y. Structural and phase transformations in a new eutectic Al-Ca-Mn-Fe-Zr-Sc alloy induced by high pressure torsion. Mater. Lett. 2019, 243, 161-164. [CrossRef] 
12. Pasebani, S.; Samimi, P.; Saber, M. Effects of scandium and hafnium solute additions on microstructure thermal stability in nanostructured ferritic alloys. Mater. Charact. 2019, 151, 216-220. [CrossRef]

13. Garcia-Martino, A.; Prieto, M.M. Practical thermal model for a radiant tubes annealing furnace. Metall. Res. Technol. 2020, 117, 109. [CrossRef]

14. Liu, X.; Guo, Z.C.; Xue, J.L.; Zhang, C. Effects of synergetic ultrasound on the Sc yield and primary $\mathrm{Al}_{3} \mathrm{Sc}$ in the Al-Sc alloy prepared by the molten salts electrolysis. Ultrason. Sonochem. 2019, 52, 33-40. [CrossRef] [PubMed]

15. Tocci, M.; Pola, A.; Girelli, L.; Lollio, F.; Montesano, L.; Gelfi, M. Wear and Cavitation Erosion Resistance of an AlMgSc Alloy Produced by DMLS. Metals 2019, 9, 308. [CrossRef]

16. Yang, Y.; Licavoli, J.J.; Sanders, P.G. Improved strengthening in supersaturated Al-Sc-Zr alloy via melt-spinning and extrusion. J. Alloys Compd. 2020, 826, 154185. [CrossRef]

17. Xiao, J.H.; Peng, Y.; Ding, W.; Chen, T.; Zou, K.; Wang, Z. Recovering scandium from scandium rough concentrate using roasting-hydrolysis-leaching process. Processes 2020, 8, 365. [CrossRef]

18. Jiang, F.; Li, H.G.; Yin, Z.M. Thermodynamic calculation on metallic thermoreduction during preparation of aluminum-rare master alloys. Trans. Nonferrous Met. Soc. China. 2001, 11, 18-21.

19. Shen, M.F. Physical Chemistry of Metallurgy; Higher Education Press: Beijing, China, 2017; pp. $247-254$.

20. Lin, C.Z.; Bai, Z.H.; Zhang, Z.R. Handbook of Thermodynamic Data on Minerals and Related Compounds; Science Press: Beijing, China, 1985; pp. 149-166.

21. Aleksandrovskii, S.V. Study on thermoanalysis process of scandium halids. J. Appl. Chem. 1997, 70, 1761-1766.

22. Xiao, J.H.; Ding, W.; Peng, Y.; Chen, T.; Zou, K.; Wang, Z. Extraction of nickel from garnierite laterite ore using roasting and magnetic separation with calcium chloride and iron concentrate. Minerals 2020, 10, 352. [CrossRef]

23. Xiao, J.H.; Zou, K.; Ding, W.; Peng, Y.; Chen, T. Extraction of lead and zinc from a rotary kiln oxidizing roasting cinder. Metals 2020, 10, 465. [CrossRef]

24. Fatimah, S.; Yoon, D.K.; Ko, Y.G. Role of $\mathrm{V}_{2} \mathrm{O}_{5}$ particles on the microstructures and corrosion behavior of Al-Mg-Si alloy via plasma electrolysis. J. Mater. Process. Technol. 2020, 284, 116757. [CrossRef]

(C) 2020 by the authors. Licensee MDPI, Basel, Switzerland. This article is an open access article distributed under the terms and conditions of the Creative Commons Attribution (CC BY) license (http://creativecommons.org/licenses/by/4.0/). 